\title{
Business model transformation toward sustainability: the impact of legitimation
}

\author{
Roberto Biloslavo \\ Department of Management, Univerza na Primorskem, Koper, Slovenia \\ Carlo Bagnoli and Maurizio Massaro \\ Department of Management, Università Ca' Foscari, Venice, Italy, and \\ Antonietta Cosentino \\ Department of Law and Economics of Productive Activities, \\ Sapienza University of Rome, Rome, Italy
}

\begin{abstract}
Purpose - This study aims to identify the legitimacy issues raised during a sustainable business model innovation, deployed by an Italian company, which was analyzed through the lens of the legitimation theory and the business model innovation theory.

Design/methodology/approach - A single case study methodology is employed for empirical research. Semistructured interviews, with top and middle management, were conducted together with the analysis of several internal and external documents, to corroborate the case analysis.

Findings - Results show how the potentiality of digital technologies allows the development of new sustainable business models, which, though, still need to gain legitimation to be accepted. The study findings allow drawing both on the business model innovation theory and on the legitimation theory, as they show how legitimation is a dynamic concept that involves internal as well as external stakeholders to support business model innovation.

Originality/value - The paper is novel, since it addresses the topic of sustainable business models development, showing how companies can get legitimation. The paper builds on existing theories and provides a practical example.
\end{abstract}

Keywords Business model, Business model innovation, Legitimation, Sustainable business model, Case study Paper type Research paper

\section{Introduction}

In the last decades, many digital technologies have been introduced into the design, production and sales processes, from robots to big data analytics and artificial intelligence (Ardito et al., 2019). Technology enables faster innovation, search for new products, processes, new ways of communication and business growth (Fletcher, 2015; Wu et al., 2018a, b; Presch et al., 2020). This is nothing new in itself (Rothwell, 1992). What is different at present is that technology has progressed more rapidly over the past few years than in the decade before (Bagnoli et al., 2019). Its cost has significantly decreased, and it has changed the expectations and behaviors of customers in almost all industries and along the entire value chain (Schniederjans and Hales, 2016). Yet, in a modern society, which is confronted with global climate problems, poverty, pollution, a lack of drinking water and adequate sanitary infrastructure, the use of digital technologies to obtain only greater efficiency, economic effectiveness and competitive advantage is too limited (Zhang et al., 2020). Current circumstances call for broader economic

(C) Roberto Biloslavo, Carlo Bagnoli, Maurizio Massaro and Antonietta Cosentino. Published by Emerald Publishing Limited. This article is published under the Creative Commons Attribution (CC BY 4.0) licence. Anyone may reproduce, distribute, translate and create derivative works of this article (for both commercial and non-commercial purposes), subject to full attribution to the original publication and authors. The full terms of this licence may be seen at http://creativecommons.org/licences/by/4.0/legalcode

Legitimation and business model transformation

Received 28 September 2019 Revised 27 March 2020 Accepted 8 May 2020 
and social changes (Dal Mas, 2019; Massaro et al., 2018; UNEP, 2012; WWF, 2014) that can satisfy the needs of consumers, both existing ones and those that are foreseen in the future, with lower consumption of resources, especially the nonrenewable ones (Walsh et al., 2020). This presumes not only more environmentally friendly product and process innovations (De Medeiros et al., 2014) but also new business models (Boons and Lüdeke-Freund, 2013; Lewandowski, 2016; Lüdeke-Freund et al., 2019) together with more transparent (O'Rourke, 2014) and sustainable supply chains (Linton et al., 2007).

Incremental process and product innovations certainly brought cleaner, more efficient, more socially conscious products and services (Asif et al., 2013; Zuo et al., 2012), but for the most part, they failed to grow beyond a premium-priced or green-lifestyle niche (Sinha et al., 2020). Still, a high percentage of consumers and companies remain unwilling to pay a premium for such advances. Alternatively, sustainable business models (SBMs) add value to various stakeholders, including customers, shareholders, the local community, the government, natural environment and even future generations (Bocken et al., 2014). In the literature, this is defined as the triple bottom line of business principles (Elkington, 1997), commonly referred to as people, planet and profit (Wilson and Post, 2013) or economy, social equity and environment (United Nations General Assembly, 2005). However, many novel SBMs have fallen short of their potential because they were unable to compete within the constraints of existing or traditional business models (BMs). Internet of things, big data analytics, artificial intelligence and blockchain, commonly known as smart technologies, can potentially change this situation (Lombardi, 2019; Piscicelli et al., 2018). However, at the moment, it is not clear how these technologies can impact on the sustainability of the environment and society. On the one hand, there is a limited understanding of how organizations need to change to embrace these technological innovations (Trequattrini et al., 2016). On the other hand, the prospective implication of smart technologies for SBM development, along the triple bottom line, remains mostly underexplored (Wu et al., 2018a, b).

Successful innovative efforts (i.e. sustainable or not) not only create new BMs but can also create new markets (e.g. Agarwal and Bayus, 2002; Knott and Posen, 2009), bring existing industries to new states, extend their life cycles and reshape their competitive landscapes. Strategic actions of an innovative firm trigger competitors' imitative reactions as well as they push organization's suppliers and other business partners to reconsider and adapt their own BMs (Saebi et al., 2017) to fit the requirements of the new de facto standard. In the final stage, the entire industry is transformed. However, this process demands the active management of several market actors as part of the strategic renewal efforts. Sustainable business model innovation (SBMI) includes not only the development and launch of a new SBMs but also intensive communication between the innovative firm and its market since the success of the proposed SBM depends on the quality of interplay between various market constituents (Boons and Lüdeke-Freund, 2013). Establishing a sufficient level of legitimacy of the SBM in the market (Lippmann, 2007) represents a significant challenge for SBMI. Influential actors such as consumers, investors, business partners play an essential role in promoting and enabling SBMI, as state and/or regulatory or professional institutions do, and concerning this, a company must take into account their different realities, which are interest-driven. For example, in the context of B2B, this means that, if company executives do not believe that a given supplier or customer has the legitimacy to demand changes to the BM the company is pursuing, they will not change it, disregarding that those changes could provide more sustainability (Lombardi et al., 2019).

Laifi and Josserand (2016) and Wu et al. (2018a, b) suggest that the pursuit of proactive legitimation strategies is vital for the success of BMI. At the same time, Snihur and Zott (2013) highlight that the acquisition of legitimacy is more challenging for a BMI than is the case of innovating a specific product, process or management technique because more stakeholders are involved in BMI than in other innovation types. As well as sustainable transition demands legitimacy is divided into two categories, internal and external. Internal legitimacy 
refers to how people in companies perceive and direct the actions that would be beneficial for their companies (Drori et al., 2013), while external legitimacy deals with the organizational environment, regulatory agencies, professional associations and reputation (Greenwood et al., 2002). However, research on legitimacy in SBM and SBMI literature is somewhat scarce. Given the uncertainty of SBMI, we suggest that organizational conformity to new established sustainable norms and practices will be possible only to the extent that those norms and practices are themselves legitimate, credible and valued (Glynn and Marquis, 2004). In that view, the communication interface between the organization and its stakeholders and the perception of legitimacy represents the next focus for research on SBMI.

The paper is novel for several reasons. Firstly, as suggested by Laifi and Josserand (2016, p. 2343), "we know very little about the strategies deployed by innovative actors to establish their legitimacy." By presenting a case study, this paper aims to contribute to filling in this gap. Additionally, previous studies on legitimation focus on the legitimation process linking pragmatic, moral and cognitive legitimation (Tolbert and Zucker, 1996; Greenwood et al., 2002; Johnson et al., 2006) or at the contingency aspects of the legitimation process such as nature, the context and the audience (Laifi and Josserand, 2016). This study applies the late approach to a specific case of SBMI. Our results suggest that the legitimization process proceeds continuously across the border between the internal and external environment of the organization and advancing along with different legitimacy types. This helps us to understand better how SBMs, when supported by digital technologies, can be developed and employed. Therefore, this paper aims to contribute to the special issue by helping to understand "how organizations need to design legitimacy strategies to effectively embrace sustainable technology solutions and the business shifts they entail."

The paper is developed as follows: the introduction is followed by a literature review on SBMI and legitimacy of BMI process, with a particular emphasis on the circular economy concept. The empirical part presents a case study of an Italian company named RigenNylon (faked name to allow anonymity), and it is focused on research design, analysis and interpretation of the data collected by semistructured interviews and a questionnaire. The final part is the conclusion, in which primary research's results are summarized, and the implications of the research for theory and practice development are presented together, with the limitations of the research.

\section{Literature review}

\subsection{Sustainable business models}

Most of the authors refer to BM indirectly or directly as the rationale of how an organization creates, delivers and captures value. This is also a very "basic" definition of Osterwalder and Pigneur (2010). However, still, there is no widely accepted and shared understanding among practitioners and scientists about what BM is (Tikkanen et al., 2005). According to Christensen et al. (2016), viewing BM as a system of interrelated elements highlights what a business is incapable of doing. The understanding of interdependencies in a BM is essential because those interdependencies create over time a kind of rigidity and pattern of behavior that makes BM hard to change.

Many traditional BMs, still remaining viable at present, may rely on mispriced resources and other market distortions that make them more competitive than they would otherwise be. As sustainability trends and challenges - including energy and commodity price fluctuation, supply insecurity or demands for transparency - continue to shift the foundations of our current BMs, incremental innovation of sole products or processes will become less and less effective in enabling companies to adapt and succeed. According to Zott et al. (2011), adopting an SBM approach helps to understand how businesses can create value not only for customers but also for other stakeholders, society and the natural environment and how this value is captured or distributed across this broad set of stakeholders. On the other hand, 
Lüdeke-Freund (2010, np) defines SBM as "a business model that creates competitive advantage through superior customer value and contributes to the sustainable development of the company and society." This definition recognizes that the core of a sustainable business is still creating and delivering customer value (Teece, 2010; Zott et al., 2011), but the environmental and social benefits are also embedded. According to Cosenz et al. (2019, p. 1), SBMs incorporate "concepts, principles, or goals that aim at sustainability, or integrating sustainability into their value proposition, value creation and delivery activities, and/or value capture mechanisms." While Lozano (2018, p. 1164) sees them as "A holistic and systemic reflection of how a company operationalizes its strategy, based on resource efficiency (through operations and production, management and strategy, organizational systems, governance, assessment and reporting, and change), so the outputs have more value and contribute to sustainability more than the inputs (with regard to material and resources that are transformed into products and services, economic value, human resources, and environmental value)."

SBMs have thus been defined as BMs that create competitive advantage through superior customer value while contributing to the sustainable development of the company and society (Lüdeke-Freund, 2010). SBM creates and delivers value that includes the economic value (i.e. economic growth - profit, return on investments, financial resilience and the long-term viability and stability of the business), social value (i.e. poverty alleviation, social justice, equality, well-being, community development, long-term employment, secure and meaningful livelihoods, labor standards and practices, wages, code of conduct, career development, health and safety and diversity) and environmental value (i.e. the use of resources at a rate at which they can be renewed, ensuring that emissions and waste are at a level that can be metabolized safely by the environment, protecting biodiversity and creating positive benefits for the environment to counter past excess). SBM hence incorporates a triple bottom line approach and considers a wide range of stakeholder interests, including the environment and the society. They are essential in driving and implementing corporate innovation for sustainability; they can help embed sustainability into business purpose and processes and serve as a critical driver for competitive advantage (Bocken et al., 2014).

\subsection{Sustainable business model innovation for circular economy}

Various authors look at the BM as a significant driver for sustainable innovation (Johnson and Suskewicz, 2009). BMI is defined as a process through which an organization changes (Dal Mas et al., 2020). According to Johnson (2010), BMI supports firms when exploiting new opportunities, in three different ways: (1) by supporting the development of new value propositions; (2) by tackling new customer segments that have been traditionally overlooked by existing value propositions; (3) by entering entirely new industries. Björkdahl and Holmén (2013) highlight that a BMI does not discover a new product or service; however, it may redefine a value proposition of an existing product or service, how it is delivered to a customer and/or how the firm profits from the customer offering. The same authors also state that: "The minimum requirement for an innovation is that it must be new to (or significantly improved for) the firm. Thus an innovation does not need to be novel to the world" (Björkdahl and Holmén, 2013 p. 215). The same position is shared by Amit and Zott (2010), who argue that a BM is innovated, even if it may not be game-changing for the industry. Johnson et al. (2008) have a different opinion and emphasize that instituting a new BM is pointless unless it is game-changing for the industry. However, all authors agree on the fact that companies often need to innovate their BMs only to preserve their market position and prevent the fall into a negative spiral from which it would be difficult to get out.

According to Foss and Saebi (2017), the need for greater sustainability (e.g. social, environmental) can be considered as a significant antecedent of BMI. Sharing economy, 
inclusive growth (Spiess-Knafl et al., 2015; Yunus et al., 2010) or target low-income consumers (Anderson and Kupp, 2008; Sánchez and Ricart, 2010) can result in significant BMI. The role of BMI in promoting sustainability is to analyze BM from the point of view of the triple bottom line (i.e. economic, social and environmental) and modifying its components in order to improve the long-term benefits firm is delivering to the society, nature and itself (Joyce and Paquin, 2016; Bocken et al., 2015).

From the sustainability point of view, waste is not only a global concern (Paritosh et al., 2018) or something useless, unwanted, defective but something that, in a process or product, even if not consistent with expected quality, could become that kind of material that is brought back to the original state and processed again. It is necessary to move from a linear economic system, based on the "take-make-dispose" paradigm, to a circular system, based on the maintenance of products in the life cycle, as long as possible (Bakker et al., 2014; Bocken et al., 2018). Fulfillment of circular economy and eco-friendly enterprises create an industrial system that allows every entity (productive or consumption, private and public) to recycle the materials to enhance the sustainability as a whole (Bag et al., 2019). The circular economy is based on the disappearance of the concept of waste through a sustainable and efficient design that allows the product to be recovered, recycled and revalued as a new resource (Ellen MacArthur Foundation, 2015; Gall et al., 2020; Lacy and Rutqvist, 2015), even leading to new waste-based circular BMs (Henry et al., 2020). Companies adopting a circular economy concept make BMI through the reconfigurations of product and processes, aiming to the creation of a closed-loop model and organizational changes along the supply chain, to ensure that everyone, during the product life cycle, guarantees the adoption of a sustainable philosophy, possibly avoiding greenwashing (Dubey et al. 2019). In particular, for managing circular BMs, the firms face up a lot of challenges that include "strategies for pricing, branding, segmentation, cannibalization problems, raw material challenges, consumer acceptance, reverse supply chain design, high innovation remanufacturing systems and short cycle times, high specificity remanufacturing processes, and the way remanufactured or reused products should be marked" (Sehnem et al., 2019, p. 1047). To be effectively implemented, the circular economy requires the participation of many stakeholders, able to encourage interventions and spread ideas, principles and benefits. First of all, companies have a central role in the adoption of this model. They must offer products and services that reduce the environmental impact and create social value by using natural resources efficiently. Customers have to adapt their buying behavior and favor sustainable products, collect waste separately and adopt leasing, rental or sharing policies. Nevertheless, it is shown that circular BMs do not accomplish the psychological, social and cultural requirements of the consumers, and barriers in the diffusion of the circular economy are due to their cognitive biases. All of these aspects, in turn, lead to barriers in the diffusion of the circular economy (Singht and Giacosa, 2019).

The circular economy gives priority to product performance and the possibility of using it, rather than having it, creating a transition from the concept of the consumer to the idea of a user (Gallaud and Laperche, 2016). Society is a crucial entity involved in the circular economy, since it must provide a legal and cultural environment able to promote large-scale standards of behavior, according to a circular model (Henry et al., 2020).

\subsection{Legitimation of sustainable business model innovation}

The term "legitimacy" refers to the state or fact of meeting rules or standards already in force that are either externally or internally defined (DiMaggio and Powell, 1991; Zucker, 1988; Berger and Luckmann, 1966; Bitektine, 2011; Tost, 2011). According to Suchman (1995); legitimacy is used in the sense of "a generalized perception or assumption that the actions of an entity are desirable, proper, or appropriate within some socially constructed system of
Legitimation and business model

transformation

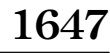


norms, beliefs, and definitions" (p. 574). Legitimacy is ascribed a central place in the institutional theory (Deephouse et al., 2017) and the strategic management literature (Suddaby et al., 2017), being defined as a process, resource and outcome of conformation to institutionally or socially defined norms, values and expectations (Oliver, 1996). Hence, legitimacy is considered as a precondition for the continuous flow of resources and the sustained support of organizational constituents (Deephouse et al., 2017; Pfeffer and Salancik, 1978) and a critical resource for corporate survival and growth (Zimmerman and Zeitz, 2002). Laifi and Josserand (2016) and Dobrev and Gotsopoulos (2010) highlight how the lack of legitimacy represents the highest risk for new ventures conducting emergent activities, but also for already established innovative actors that try to break a status quo situation within an industry. Institutional theorists have argued that innovation will become legitimate when it is judged acceptable and desirable by the users (Suchman, 1995), in the case of SBMI that means to be acceptable and desirable by a multitude of stakeholders involved into the company's value system.

Within the literature, different types of legitimacy are mentioned (Tang, 2017). For example, Jaber and Oftedal (2020) used three institutional dimensions (regulative, normative and cognitive) to measure legitimacy in an organization under a sustainable change. However, the most often used is Suchman's (1995) three-dimensional framework distinguishing between pragmatic, moral and cognitive legitimacy. Pragmatic legitimacy "is based on calculating the individual interests of the organization's immediate audiences. This immediacy means that direct exchanges take place between the organisation and its audience" (Suchman, 1995, p. 578). A pragmatic legitimacy is a form of "exchange legitimacy" (Suchman, 1995, p. 578), which provides instrumental, practical value to the organization. In the case of supporting sustainable activities carried by a supplier or customer, it means concrete benefits for an organization such as cost cutting, better reputation, increased profits, new markets or, in case of sustainability, reduced costs due to improved resource efficiency, reduced risk of legal liability, enhanced reputation or improved brand image (Thomas and Lamm, 2012). Thus, business partners, when seen as means able to promote economic profit, will be accorded pragmatic legitimacy. Moral legitimacy refers to a kind of company ready to encourage sustainability and perceived as having moral value, accordingly to the normative values of observers (Reuber and Morgan-Thomas, 2019). Moral legitimacy rests on a judgment by stakeholders regarding "whether the activity is the right thing to do" (Suchman, 1995, p. 574). Such judgments generally reflect explicit individual's beliefs, allowing the evaluation of whether an activity is prosocial or not (Suchman, 1995, p. 579). Finally, cognitive legitimacy is based on culturally embodied reality or shared cultural-cognitive schemas, which are so deeply assimilated and widespread that the question of not submitting to it or of transgressing it does not even arise (Berger and Luckmann, 1966). In a way, cognitive legitimacy can be considered as a passive evaluation, distinct from the more effortful, elaborative judgments required to assess pragmatic and moral legitimacy. Based on this three-dimensional framework, different frameworks were proposed concerning the sequences of legitimation and the relative importance of the three dimensions of legitimacy at the various stages (Tolbert and Zucker, 1996; Greenwood et al., 2002; Johnson et al., 2006; Laïfi and Josserand, 2016).

In our research, we applied the four-dimensional framework proposed by Laifi and Josserand (2016) that is composed of "the nature of legitimacy, the aspect(s) of practice being subject to legitimation, the context where legitimacy is sought, and the audience targeted" (p. 2344). The nature of legitimacy considers different phases of legitimation development and in that view "cognitive legitimacy is a long-term achievement that emerges after pragmatic and moral legitimisation have occurred" (Laïfi and Josserand, 2016, p. 2349). The practice is subjected to legitimation and is thus represented by components of the organization of the BM, in our case of the SBM, which needs to be legitimated by different 
stakeholders (Hacklin and Wallnöfer, 2012). A third dimension is that of contexts in which different legitimation strategies are defined. The final, fourth dimension considers diverse stakeholders or audiences that have different needs and thus a different view about what is acceptable and desirable. In our case, the influential actors considered are business actors along the entire value chain, from suppliers to customers, to users and to professional institutions, as well as internal audiences, which the company must take into account to successfully employ a new SBM.

\section{Methodology}

\subsection{Research method and context}

In the development of our research method, we decided to employ a case study research method, since case studies are particularly useful when researchers need to investigate how a phenomenon has been developed through a "contemporary set of events over which the investigator has little or no control" (Yin, 2014, p. 1913). Moreover, trying to bridge the gap between academia and practice, case studies are more understandable by practitioners, allowing thus easier replicability of results and lessons learned (Dal Mas et al., 2019). Case study research is also useful to provide a freshness of perspectives to a previously researched topic (Eisenhardt, 1989). Furthermore, a single case study with multiple levels of analysis is applied to achieve richer and more multifaceted insights (Yin, 2014).

To develop our analysis, we focus on the case of RigenNylon (the name of the organization has been faked to ensure anonymity). RigenNylon was founded in Italy in 1965, and the first plant opened in Trento, in the north-eastern part of Italy. Progressively, RigenNylon has implemented a process of business development, opening several branches, nationally and internationally, becoming a global leader in the production of Polyamide 6, also known as Nylon 6. RigenNylon currently represents a globally developed group, with 16 plants employing more than 2,700 people in eight countries and three continents, with a turnover of almost $600 \mathrm{~m}$ euros.

Interestingly, only recently, the company started a formal R\&D process. Using several new technologies, the company was able to develop a method to regenerate Polyamide 6, starting from wasted products, such as fishing nets, carpets and rigid textiles. The regenerate polymer, named Econyl ${ }^{\circledR}$, owns the same characteristics of a newly generated Nylon. However, despite being equal to the original polymer, the regenerated product requires a different, that is, SBM that involves the garbage collection as well as the new value proposition. Econyl's case was well received by both customers and by the press, with several online and printed articles worldwide. According to the four typologies of BM transformation toward sustainability proposed by Lewandowski (2016), we can put the RigenNylon case into the fourth typology of BM redesign that includes a complete rethinking of organization's BM elements, resulting into a radically new value proposition. Therefore, considering our research aim, given the company's vision, results and philosophy, we believe RigenNylon represents a critical and revelatory research context (Yin, 2014) providing us with a "polar type" to observe the process of interest (Eisenhardt, 1989).

\subsection{Data collection and analysis}

To develop our analysis, we employed a research protocol, since "without such documentation you could not even repeat your work - which is another way of dealing with reliability" (Yin, 2014, p. 1699). We collected multiple sources of evidence (Yin, 2014). First, we collected semistructured interviews from 11 members of the organization, ranging from the CEO to several managers, such as the Chief Operation Officer, the Chief Innovation Officer and the Chief ICT Officer. According to Qu and Dumay (2011, p. 246), "the
Legitimation and business model transformation 
semi-structured interview involves prepared questioning guided by identified themes in a consistent and systematic manner interposed with probes designed to elicit more elaborate responses." The questions focused on the overall comprehension of the company's history, its $\mathrm{BM}$, change and future developments. Additionally, we analyzed several internal documents, such as the strategic plan, the annual report and the corporate social responsibility report, as well as some external material (such as the company's website and the social media channels). Finally, we developed a questionnaire focused on the analysis of RigenNylon BM, filled in by 39 middle managers. The following table summarizes the data collection and analysis (see Table 1).

All the collected data were manually coded, using in vivo coding, and discussed among the authors, to achieve investigator triangulation (Yin, 2014). The framework proposed by Laifi and Josserand (2016) represented a coding grid that helped us in categorizing the text of the interviews into the four dimensions of legitimation.

\section{Findings}

This section summarizes the results of our analysis. We present results in chronological order. All results are then summarized in Table 2.

\subsection{The triggers of the new sustainable business model}

The trigger of the process that we aim to analyze in light of the legitimacy theory firstly is the early stage of the Econyl innovation. At the beginning of 2000, RigenNylon detected a significant reduction in orders because its most important customer, a global carpet tile manufacturer, decided they would only buy eco-sustainable products. The CEO of RigenNylon's most important customer was visionary, and already at the end of the

Table 1.

Data collection and analysis

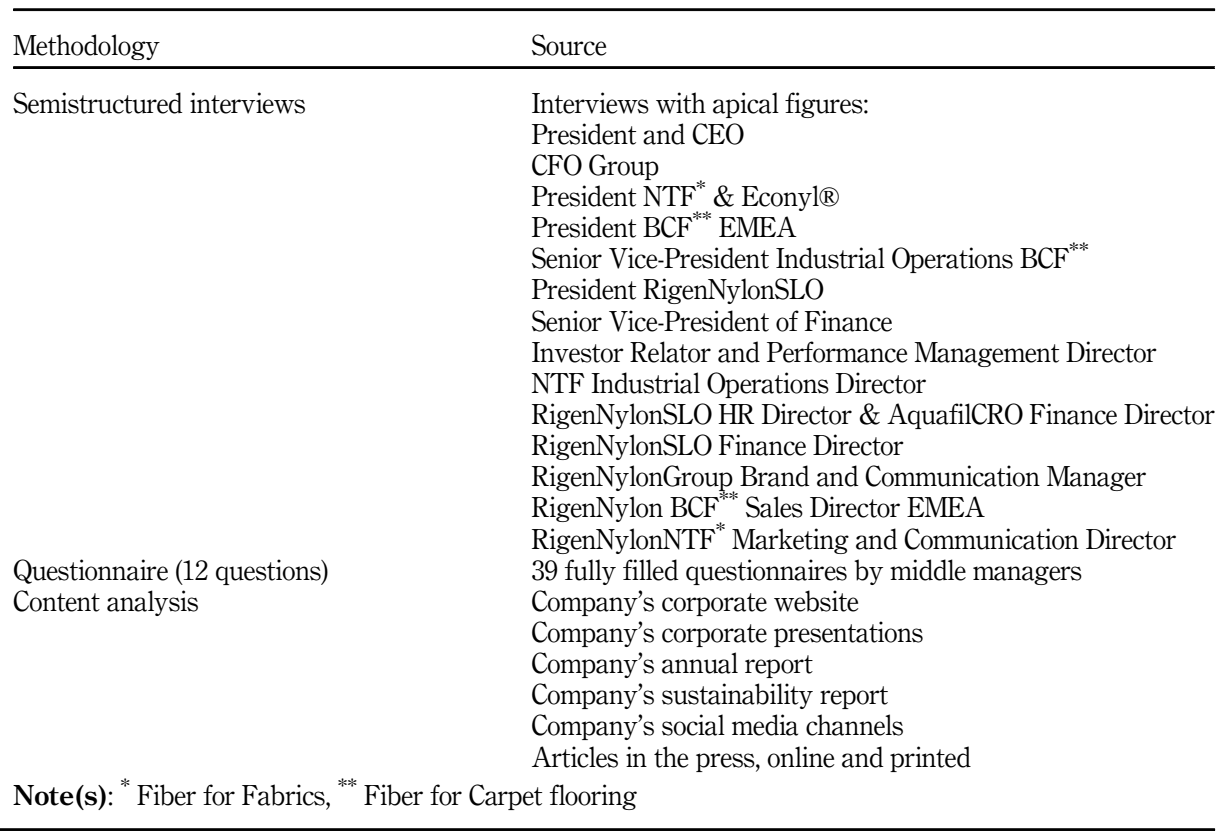

\author{
Interviews with apical figures: \\ President and CEO \\ President $\mathrm{BCF}^{* *}$ EMEA \\ Senior Vice-President Industrial Operations $\mathrm{BCF}^{* *}$ \\ Investor Relator and Performance Management Director \\ TF Industrial Operations Director \\ RigenNylonSLO HR Director \& AquafilCRO Finance Director \\ RigenNylonSLO Finance Director \\ RigenNylon $\mathrm{BCF}^{* *}$ Sales Director EMEA \\ RigenNylonNTF* Marketing and Communication Director \\ Company's annual report \\ Company's sustainability report \\ Articles in the press, online and printed
}

Note(s): ${ }^{*}$ Fiber for Fabrics, ${ }^{* *}$ Fiber for Carpet flooring 


\begin{tabular}{|c|c|c|c|}
\hline phase & Main points & Legitimacy theory & \\
\hline $\begin{array}{l}\text { The triggers of the new sustainable } \\
\text { business model }\end{array}$ & $\begin{array}{l}\text { Requests from customers } \\
\text { Start of a massive R\&D program } \\
\text { Redesign of the whole BM } \\
\text { Introduction of a new product line } \\
\text { Technological implementation }\end{array}$ & Pragmatic & $\begin{array}{r}\text { model } \\
\text { transformation }\end{array}$ \\
\hline The supply chain development & $\begin{array}{l}\text { Need for waste collection } \\
\text { Alliances with other partners of the } \\
\text { supply chain }\end{array}$ & $\begin{array}{l}\text { Pragmatic and } \\
\text { moral }\end{array}$ & 1651 \\
\hline The extension to other supply chains & $\begin{array}{l}\text { Expansion of the alliance } \\
\text { involvement of opinion leaders }\end{array}$ & $\begin{array}{l}\text { Moral and } \\
\text { cognitive }\end{array}$ & $\begin{array}{r}\text { Table } 2 . \\
\text { Main findings }\end{array}$ \\
\hline
\end{tabular}

nineties, he began to reflect on sustainability, circular economy and eco-sustainability (Anderson and Lanier, 2019). As told by one of the managers we interviewed:

In 1998, the CEO of this major company made a meeting in Maui, one of the most beautiful islands and environments in the world, bringing more than 800 people from all over the world to instruct them on sustainability. He called us in a room and theorizes his Mission Twenty Twenty, saying: 'Look, guys, for 2020, I want to regenerate the world through production'. Everyone thought he was crazy.

Due to its strong commitment on reaching a more sustainable market, the orders of this customer dropped dramatically at the beginning of the new millennium causing a turnover reduction of more than $70 \%$, since some competitors of RigenNylon started developing yarns made of a certain small percentage of recycled material. One of the managers said:

it was a dramatic period, where we started to re-think about our business model, to reach this new requirement. It was not easy for us.

One of the main problems was to start an expensive research and development plan to change the product, first, and the whole BM, later. The CEO declared:

I remember when a manager of an important bank visited us and when I told him that our idea was to transform a rubbish dump in a gold mine he walked away laughing ... note the bank went bankrupt while we are still here, growing.

Several managers wanted to reduce the overall cost structure to be able to keep the financial sustainability. However, RigenNylon CEO was able to obtain the required financial resources to develop an R\&D project, even if the financial institution that they mostly cooperated with at that time denied them the needed capital, despite the clear advantages of the new product in terms of environmental sustainability.

Interestingly, the same bank did not survive the global financial downturn that followed in 2008. The CEO highlighted:

I was convinced that we could have made it much better than our competitors. With [names of the other members of the board] we do things always together, but they were sceptical. However, I was convinced that, if we had not been able to change and become more sustainable, we would have disappeared. When I found the money, we had the resources, and everyone was on board.

These words lead to one first result, recognizing that legitimacy is related to not only external stakeholders but also internal ones, as the CEO firstly needed to get internal legitimacy to start developing a new product innovation. A relevant amount of money was spent in R\&D, and in 2010 a new totally sustainable product was born: Econyl. Econyl is a polyamide made from $100 \%$ recycled raw materials that include postconsumer waste such as fishing nets, 
carpets, clothing, rugs and rigid textiles, as well as preconsumer waste such as oligomers, scraps and others generated from the production of Nylon 6. Econyl turns consumer waste into fashion and interior products such as clothes and carpets. Every regenerated yarn by RigenNylon has the same physical characteristics and functional performance as traditional nylon 6 , but provides higher sustainable value in a process that can be repeated without limitations. As the strategic plan of the company states:

No waste. No new resources. Only endless possibilities since the material might be regenerating without any limit.

The production process is made possible due to the use of several technologies. While chemistry-based methods enable the regeneration of the polymers, smart technologies are used to collect and select the proper waste. The overall production has been properly used to produce the yarns with a technology named "smart ply" that aggregates two different phases of the production process. Interestingly, while the production process was perfectly functioning, the company started having several problems in deploying the overall business model. The main source of regenerated nylon is made of fishing nets recovered in the seas, oceans and aquaculture and additional nylon waste coming from preconsumer and postconsumer, such as fabric scraps from mills and carpets destined for landfill. The company needed to develop a collection process and had to motivate suppliers to collect and preserve what normally is considered as waste. The CEO stated:

when I see a rubbish dump, I see a gold mine. However, starting a collecting process was not so easy ... in a gold mine you just have to mine, we had to convince the owners to give us their garbage.

Additionally, despite the primary customer, the overall market was not so keen on accepting recycled products. It was clear that there is some economic value in the new product, but there were other issues that potential customers had difficulties in taking. One of the managers highlighted:

We had several problems with our customers. On the one hand, several customers were sceptical. The main question was: will ever a consumer drink from a bottle made of garbage?

RigenNylon was able to get pragmatic legitimacy internally and with the main customer, but at this point, it was not able to develop moral legitimacy among suppliers and even less the cognitive legitimacy needed to convince mainstream customers.

\subsection{The supply chain development}

Once the production of Econyl had begun, and the trust of the leading customer was regained, RigenNylon still had to convince its suppliers to collect the material, to be regenerated thanks to the new technology adopted. To date, the company's turnover coming from circular economy had grown by $6.5 \%$ in financial year 2018 compared to 2017 , representing almost $37 \%$ of the total fiber sales, with the main obstacles to the increasing production represented by the difficulty of collecting the waste to be regenerated.

Indeed, considering the legitimacy approach, the relationships between RigenNylon and the waste collectors were crucial for the success of the new SBM. For this reason, in 2012, RigenNylon joined Net-Works, an umbrella business that involves a partnership between a carpet manufacturer (Interface), a yarn producer (namely RigenNylon) and a conservation charity (Zoological Society of London, known as ZSL) sharing the common aim to "redesign global supply chains to create sustainable and scalable solutions that deliver less plastic and more fish in the oceans" [1]. In detail, Interface provides business strategy, start-up capital and a global network; ZSL provides conservation expertise, local community organization and local partner development; and RigenNylon contributes with an innovative regeneration process that recycles the nets into yarn [2]. Such a network allows combining business 
acumen with sustainable development, generating benefits both for local communities and for the natural ecosystem. More precisely, in Asia, thanks to the collaboration with Net-Work, the company collects worn fishing nets through small social businesses.

Initially, sustainability had been permanently recognized by RigenNylon's CEO as necessary for the company's reputation and economic survival; however, the influence of Interface's CEO has triggered the transition toward the recognition of the moral dimension of sustainability. As stated by RigenNylon's CEO:

[...] We have transformed our linear business model into a circular business model. We are closing the loop by not taking fossil fuels from the planet and by diverting waste from landfill. I think in

20 years we will either be fully sustainable or we will be out of the market.

It is quite easy to guess that, inside RigenNylon, pragmatic legitimacy turned into moral and cognitive legitimacy, not only within the carpets division influenced by Interface's vision but also in all the divisions of the company.

\subsection{The extension to other supply chains}

The available data show that, so far, RigenNylon's strategy has been to move toward the sectors where Nylon 6 is extensively used, for example, the BCF (Bulk Continuous Filament) yarn for carpets. However, historical and prospective data show that, from 2020 to 2030, the $\mathrm{BCF}$ may absorb a relevant but not growing market share, while the growing sectors seem to be the ones of yarn productions for NTF (Nylon Textile Filaments) and LP garments. The company should try to expand to other sectors. This willingness is confirmed by RigenNylon's CEO, who declared:

The carpet and textile industries grow slowly. Econyl must be exploited for finished products [...] the yarn can be used for working clothes for prison personnel, military overalls, tents, [. . .] we want to find new applications and manage them directly, so that, instead of just selling the semi-finished product, more value is created, and the brand awareness leveraged.

There is not only an economic reason to consider other sectors besides the BCF yarn sector, but also the vision of the RigenNylon's CEO, who highlighted:

[...] through Econyl [ . . . we manage to change the sector, to find solutions to some serious pollution problems regarding plastics, sea, textiles and so on; in my opinion, one could even set up a sales business of sustainable products.

However, starting from the analyzed data, it is possible to say that, in the BCF yarn sector, RigenNylon has affirmed customer intimacy and ecosystem leadership that have a positive impact on pragmatic legitimacy. In contrast, the same approach has not been followed for developing the cloth sectors or other ones. In the production of yarn for garments, it seems that the focus is only on the sustainability of Econyl. Considering that Econyl per se does not involve any specific function besides its complete recycle, it mainly conveys the moral value linked to the environment. Therefore, without direct economic advantages, such as product's price, or indirect ones, such as enhanced reputation or improved brand image, which are elements of the pragmatic legitimacy, RigenNylon is in the position to use only moral legitimacy as a mean to sell the product. However, this is not a market position that RigenNylon can sustain in the long term. Besides developing moral legitimacy, RigenNylon should work on pragmatic and cognitive legitimacy. For example, cognitive legitimacy can be developed by taking advantage of opinion leaders, for example, through the partnership with Net-Works. Also, taking advantage of the experiences achieved in the $\mathrm{BCF}$ yarn sector, RigenNylon should work in two directions. The first is a process of building and promoting its brand identity of a sustainable company. More robust brand recognition can support RigenNylon in acquiring pragmatic legitimacy as advocated by
Legitimation and business model

transformation 
Deephouse and Carter (2005). In this case, pragmatic legitimacy focuses specifically on the meaning of the product in its essentially moral dimension. The other direction, instead, goes toward the development of customer intimacy and ecosystem leadership by proposing itself as a reference pin for a portfolio of different sustainable products. As one of the managers said:

If we want to succeed, we not only need to produce the best product, but it must also be affordable.

Both the objectives need time to be accomplished but represent the next step of legitimacy development among external stakeholders that includes moral as well as pragmatic and cognitive legitimacy.

The following table summarizes the main findings.

\section{Discussion and conclusion}

The exploration of our findings reveals the development of RigenNylon's SBMI legitimacy process, which is represented in Figure 1. The sine wave is used only to illustrate the ongoing dialogue between the internal and external audiences of the company, intending to develop legitimacy for Econyl. The encounter with the leading customer CEO has represented the external trigger, which fostered RigenNylon's CEO to turn into sustainability. Firstly, pragmatic legitimacy emerges and evolves with the search for funds to develop Econyl's sustainable product. The institutionalization of pragmatic legitimacy is leveraged by the involvement of the top management of the company's core division and the subsequent engagement of suppliers and partners. In this phase, moral legitimacy starts to emerge, convincing internal and external audiences that the implementation of sustainability is the right thing to do. The path returns internally to instill the sustainability value in the middlemanagement tiers of the other divisions of the company, to start the search for new applications of the product. Indeed, in the end, the wave flows into the external dimension, reflecting the willingness to expand to other supply chains. In this last phase, moral legitimacy is institutionalized and cognitive legitimacy starts to emerge.

Now concluding our study, we would like to start from the reasons that originated the research. Undoubtedly, the capture of large amounts of data and their analysis, using smart analytics, as well as the cut of cost in the production and other business processes (i.e. automation and simplification) are significant for organization effectiveness. Still, smart technologies can also contribute to the local community development and other environmental aspects of the triple bottom as social innovations show. Smart technologies provide new opportunities for BMI, but management needs to take a holistic view of the BM in order to make innovation effective.

Moreover, the development of a more sustainable solution, at the same cost of a less sustainable or traditional one, is not enough in itself. As the RigenNylon case clearly shows, an SBM often requires to involve the whole value chain, and to operate effectively, it must get proper legitimacy internally among employees and from the market actors involved, including customers, suppliers and financing institutions above all. A company that wants to establish a new SBM must answer three key questions first: 1. Do market actors believe there is a "business case" for them? 2. Do they believe that this is the "right" thing to do? 3. Do they believe that this will simplify their business or not?

Indeed, considering the relevance of the material's function, Econyl does not involve a specific purpose, it mainly conveys the moral value linked to the sustainability of the environment. Therefore, the customers do not acquire any particular advantage in terms of the product's price and functionality, which remain the same. For this reason, moral legitimacy is a paramount with both suppliers and customers, to convince them to support the new BM. In the RigenNylon case, the pursuit of moral legitimacy, by emphasizing the 

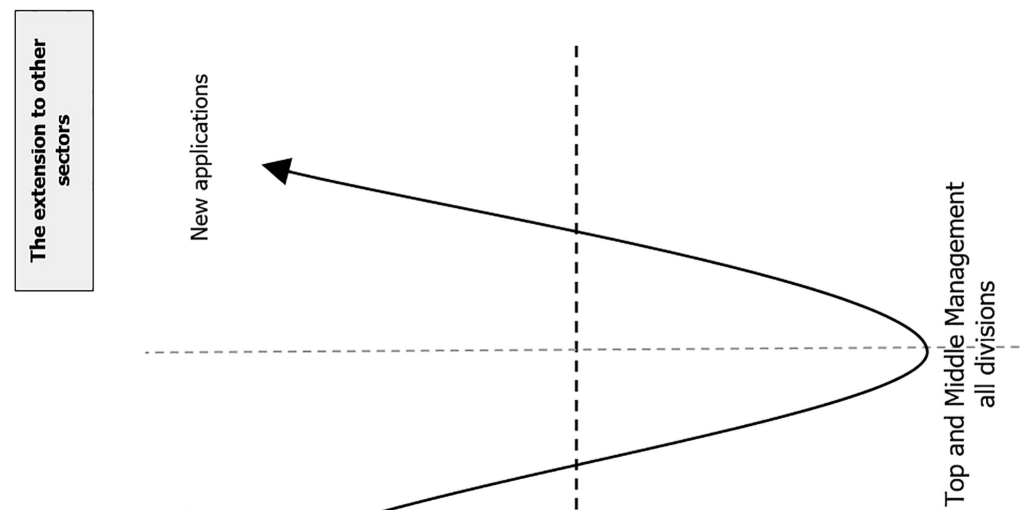

Legitimation and business model transformation

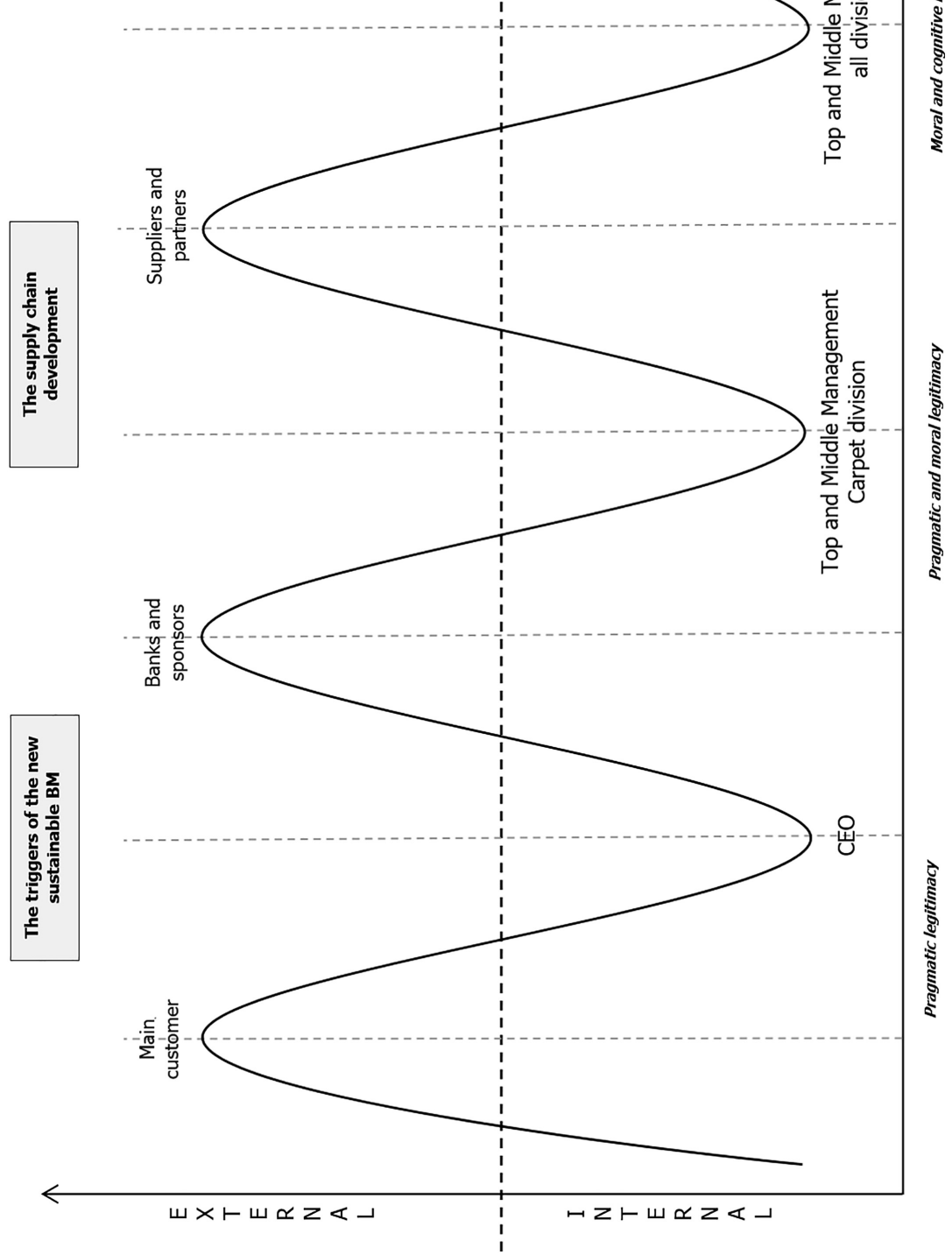

Figure 1. The virtual cycle of legitimation of the analyzed company 
environmental and social aspect of sustainability, seems to overcome the more pragmatic "business case" arguments that emphasize the possible higher profit margins for green products, enhanced reputation or improved brand image. This is a piece of essential information for marketing communication and brand identity awareness, as according to Branco et al. (2008) "Companies are supposed not only to have activities which are congruent with social values but also to communicate that their activities are congruent with such values" (p. 138).

Our contribution to the literature is based on practical guidelines for legitimacy strategy development in case of SBMI. Organization must first of all be open to external triggers that can sustain development of pragmatic legitimacy internally to organization and specifically among top management. The external triggers can consist of the external or hierarchical pressure (coercive isomorphism) that in our case is represented by the most important organization's customers or through modeling other sustainable organizations (mimic isomorphism). Pragmatic legitimacy among organizational top management leads into two development directions. The first direction is toward external sponsors that help allocate budgets and resources and align critical stakeholders. The second direction with a time delay goes to development of pragmatic and moral legitimacy among middle and operational management. When the internal pragmatic and moral legitimacy are achieved, organizational members are effectively mobilized around a common strategic and ideological vision of sustainability (Drori and Honig, 2013), which can now act as a tool that further reinforces organizational sustainable practices. Only now organization is ready to adapt a new mind-set that can result in development of new sustainable solutions or SBMI. However, SBMI cannot be sustained without a proper support of external stakeholders, at this stage above all suppliers and partners. For this reason the legitimation process shifts outward again. At the same time organization needs to support internalization of legitimacy process that consists of continuous individual and collective reflection and the ability to see connections and recognize patterns as well as to make sense between different ideas and concepts. From that point on the legitimacy process can be extended to other business units or programs to sustain the new developed SBM. Finally, while most of the studies on legitimacy focus on a one-way evolution process, our results show that legitimation is a complex process that involves internal and external actors, creating a virtuous cycle of engagement and continuous involvement.

Like all researches, this study has some limitations. Firstly, it focuses on a specific business sector where the regenerated product has the same characteristics as the new one. Additionally, RigenNylon produces a raw material, not a final product. Different situations, where the regeneration/recycled product provides different characteristics or the product is sold to final customer, might show differences if compared to our results. However, we believe that those might represent further opportunities to develop new studies on the topic, understanding, for instance, the customers' choices in selecting one more sustainable product instead of a traditional one. It would be also interesting to extend the interviews to the different external stakeholders (and not just the managers) in order to obtain a view from outside the organization of how its SBM is perceived. This would make it possible to compare answers and determine whether the view from the "outside" is similar to that from the "inside."

Being the case of polar type, it ensures replicability of the results to other organizations or business fields.

\section{Notes}

1. http://net-works.com

2. http://net-works.com/about-net-works/partners/ 


\section{References}

Agarwal, R. and Bayus, B. (2002), "The market evolution and sales takeoff of product innovations", Management Science, Vol. 48, pp. 1024-1041.

Amit, R.H. and Zott, C. (2010), "Business model innovation: creating value in times of change", IESE Business School Working Paper, No. 870.

Anderson, J. and Kupp, M. (2008), "Serving the poor: drivers of business model innovation in mobile", Info, Vol. 10 No. 1, pp. 5-12.

Anderson, C.R. and Lanier, J.A. (2019), Mid-Course Correction Revisited: The Story and Legacy of a Radical Industrialist and His Quest for Authentic Change, Chelsea Green Publishing, London.

Ardito, L., Scuotto, V., Del Giudice, M. and Petruzzelli, A.M. (2019), "A bibliometric analysis of research on big data analytics for business and management", Management Decision, Vol. 57 No. 8, pp. 1993-2009.

Asif, M., Searcy, C., Zutshi, A. and Fisscher, O.A. (2013), "An integrated management systems approach to corporate social responsibility", Journal of Cleaner Production, Vol. 56, pp. 7-17.

Bag, S., Gupta, S. and Foropon, C. (2019), "Examining the role of dynamic remanufacturing capability on supply chain resilience in circular economy", Management Decision, Vol. 57 No. 4, pp. 863-885.

Bagnoli, C., Dal Mas, F. and Massaro, M. (2019), "The 4th industrial revolution: business models and evidence from the field", International Journal of E-Services and Mobile Applications, Vol. 11 No. 3, pp. 34-47.

Bakker, C., Hollander, M.d., van Hinte, E. and Zijlstra, Y. (2014), Products that Last: Product Design for Circular Business Models, TU Delft Library, Delft.

Berger, P.L. and Luckmann, T. (1966), The Social Construction of Reality: A Treatise on the Sociology of Knowledge, Irvington Publishers, New York, NY.

Bitektine, A. (2011), "Toward a theory of social judgments of organizations: the case of legitimacy, reputation, and status", Academy of Management Review, Vol. 36 No. 1, pp. 151-179.

Björkdahl, J. and Holmén, M. (2013), "Editorial: business model innovation-the challenges ahead", International Journal of Product Development, Vol. 18 No. 42828, pp. 213-225.

Bocken, N.M.P., Short, S.W., Rana, P. and Evans, S. (2014), "A literature and practice review to develop sustainable business model archetypes", Journal of Cleaner Production, Vol. 65, pp. 42-56.

Bocken, N.M.P., Rana, P. and Short, S.W. (2015), "Value mapping for sustainable business thinking", Journal of Industrial and Production Engineering, Vol. 32 No. 1, pp. 67-81.

Bocken, N.M.P., Schuit, C.S.C. and Kraaijenhagen, C. (2018), "Experimenting with a circular business model: lessons from eight cases", Environmental Innovation and Societal Transitions, Vol. 28, pp. 79-95.

Boons, F. and Lüdeke-Freund, F. (2013), "Business models for sustainable innovation: state-of-the-art and steps towards a research agenda", Journal of Cleaner Production, Vol. 45, pp. 9-19.

Branco, M., Eugenio, T. and Ribeiro, J. (2008), "Environmental disclosure in response to public perception of environmental threats - the case of co-incineration in Portugal", Journal of Communication Management, Vol. 12 No. 2, pp. 136-151.

Christensen, C.M., Bartman, T. and Van Bever, D. (2016), "The hard truth about business model innovation”, MIT Sloan Management Review, Vol. 58 No. 1, pp. 31-40.

Cosenz, F., Rodrigues, V.P. and Rosati, F. (2019), "Dynamic business modeling for sustainability: exploring a system dynamics perspective to develop sustainable business models", Business Strategy and the Environment April, pp. 1-14.

Dal Mas, F. (2019), "The relationship between intellectual capital and sustainability, An analysis of practitioner's thought", in Matos, F., Vairinhos, V., Selig, P.M. and Edvinsson, L. (Eds), Intellectual Capital Management as a Driver of Sustainability, Springer, Cham, pp. 11-24.
Legitimation and business model

transformation 
$\mathrm{MD}$

58,8

Dal Mas, F., Massaro, M., Lombardi, R. and Garlatti, A. (2019), "From output to outcome measures in the public sector: a structured literature review", International Journal of Organizational Analysis, Vol. 27 No. 5, pp. 1631-1656.

Dal Mas, F., Piccolo, D., Edvinsson, L., Skrap, M. and D'Auria, S. (2020), "Strategy innovation, intellectual capital management and the future of healthcare, The case of kiron by nucleode", in Matos, F., Vairinhos, V., Salavisa, I., Edvinsson, L. and Massaro, M. (Eds), Knowledge, People, and Digital Transformation: Approaches for a Sustainable Future, Springer, Cham.

De Medeiros, J.F., Ribeiro, J.L.D. and Cortimiglia, M.N. (2014), "Success factors for environmentally sustainable product innovation: a systematic literature review", Journal of Cleaner Production, Vol. 65, pp. 76-86.

Deephouse, D.L. and Carter, S.M. (2005), "An examination of differences between organizational legitimacy and organizational reputation”, Journal of Management Studies, Vol. 42 No. 2, pp. 329-360.

Deephouse, D.L., Bundy, J., Tost, L.P. and Suchman, M.C. (2017), "Organizational legitimacy: six key questions", in Greenwood, R., Oliver, C., Lawrence, T. and Meyer, R. (Eds.), The SAGE Handbook of Organizational Institutionalism, 2nd ed., Sage, London, pp. 27-52.

DiMaggio, P.J. and Powell, W.W. (1991), "Introduction”, in DiMaggio, P.J. and Powell, W.W. (Eds.), The New Institutionalism in Organizational Analysis, University of Chicago Press, Chicago, pp. 1-38.

Dobrev, S.D. and Gotsopoulos, A. (2010), "Legitimacy vacuum, structural imprinting, and the first mover disadvantage", Academy of Management Journal, Vol. 53 No. 5, pp. 1153-1174.

Drori, I. and Honig, B. (2013), "A process model of internal and external legitimacy", Organization Studies, Vol. 34, pp. 345-376.

Dubey, R., Gunasekaran, A., Childe, S.J., Papadopoulos, T. and Helo, P. (2019), "Supplier relationship management for circular economy: influence of external pressures and top management commitment”, Management Decision, Vol. 57 No. 4, pp. 767-790.

Eisenhardt, K.M. (1989), "Building theories from case study research", Academy of Management Review, Vol. 14 No. 4, pp. 532-550.

Elkington, J. (1997), Cannibals with Forks: The Triple Bottom Line of 21st Century Business, New Society Publishers, Stoney Creek.

Ellen MacArthur Foundation (2015), Circular Economy: Business Rationale For An Accelerated Transition, available at: https://www.ellenmacarthurfoundation.org/assets/downloads/TCE_ Ellen-MacArthur-Foundation_9-Dec-2015.pdf.

Fletcher, D. (2015), "Internet of things", in Blowers, M. (Ed.), Evolution of Cyber Technologies and Operations to 2035, Springer, New York, NY, pp. 19-32.

Foss, N.J. and Saebi, T. (2017), "Fifteen years of research on business model innovation: how far have we come, and where should we go?”, Journal of Management, Vol. 43 No. 1, pp. 200-227.

Gall, M., Wiener, M., Chagas de Oliveira, C., Lang, R.W. and Hansen, E.G. (2020), "Building a circular plastics economy with informal waste pickers: recyclate quality, business model, and societal impacts", Resources, Conservation and Recycling, Vol. 156 May, 104685.

Gallaud, D. and Laperche, B. (2016), Circular Economy, Industrial Ecology and Short Supply Chain, ISTE, London.

Glynn, M.A. and Marquis, C. (2004), "When good names go bad: symbolic illegitimacy in organization”, Research in the Sociology of Organizations, Vol. 22, pp. 147-170.

Greenwood, R., Suddaby, R. and Hinings, C. (2002), "Theorizing change: the role of professional associations in the transformation of institutionalized fields", Academy of Management Journal, Vol. 45 No. 1, pp. 58-80.

Hacklin, F. and Wallnöfer, M. (2012), "The business model in the practice of strategic decision making: insights from a case study", Management Decision, Vol. 50 No. 2, pp. 166-188. 
Henry, M., Bauwens, T., Hekkert, M. and Kirchherr, J. (2020), "A typology of circular start-ups: analysis of 128 circular business models", Journal of Cleaner Production, Vol. 245 February, 118528.

Jaber, T. and Oftedal, E.M. (2020), "Legitimacy for sustainability: a case of a strategy change for an oil and gas company", Sustainability, Vol. 12 No. 2, p. 525.

Legitimation and business model transformation

Johnson, M.W. (2010), "The time has come for business model innovation”, Leader to leader, Vol. 2010 No. 57 , pp. 6-10.

Johnson, M.W. and Suskewicz, J. (2009), "How to jump-start the clean economy", Harvard Business Review, Vol. 87 No. 11, pp. 52-60.

Johnson, C., Dowd, T. and Ridgeway, C. (2006), "Legitimacy as a social process", Annual Review of Sociology, Vol. 32, pp. 53-78.

Johnson, M.W., Christensen, C.M. and Kagermann, H. (2008), "Reinventing your business model", Harvard Business Review, Vol. 86 No. 12, pp. 50-59.

Joyce, A. and Paquin, R.L. (2016), "The triple layered business model canvas: a tool to design more sustainable business models", Journal of Cleaner Production, Vol. 135, pp. 1474-1486.

Knott, A.M. and Posen, H.E. (2009), "Firm R\&D behavior and evolving technology in established industries", Organization Science, Vol. 20 No. 2, pp. 352-367.

Lacy, P. and Rutqvist, J. (2015), Waste to Wealth: The Circular Economy Advantage, Palgrave Macmillan, London.

Laifi, A. and Josserand, E. (2016), "Legitimation in practice: a new digital publishing business model", Journal of Business Research, Vol. 69, pp. 2343-2352.

Lewandowski, M. (2016), "Designing the business models for circular economy-towards the conceptual framework", Sustainability, Vol. 8 No. 1, p. 43.

Linton, J.D., Klassen, R. and Jayaraman, V. (2007), "Sustainable supply chains: an introduction", Journal of Operational Management, Vol. 25, pp. 1075-1082.

Lippmann, S. (2007), "The institutional context of industry consolidation: radio broadcasting in the United States, 1920-1934", Social Forces, Vol. 86 No. 2, pp. 467-495.

Lombardi, R. (2019), "Knowledge transfer and organizational performance and business process: past, present and future researches", Business Process Management Journal, Vol. 25 No. 1 , pp. 2-9.

Lombardi, R., Trequattrini, R., Cuozzo, B. and Cano Rubio, M. (2019), "Corporate corruption prevention, sustainable governance and legislation: first exploratory evidence from the Italian scenario", Journal of Cleaner Production, Vol. 217, pp. 666-675.

Lozano, R. (2018), "Sustainable business models: providing a more holistic perspective", Business Strategy and the Environment, Vol. 27 No. 8, pp. 1159-1166.

Lüdeke-Freund, F. (2010), Towards a Conceptual Framework of 'Business Models for Sustainability', RSCP-EMU Conference, Delft, 2010, pp. 1-28.

Lüdeke Freund, F., Gold, S. and Bocken, N.M.P. (2019), "A review and typology of circular economy business model patterns", Journal of Industrial Ecology, Vol. 23 No. 1, pp. 36-61.

Massaro, M., Dumay, J., Garlatti, A. and Dal Mas, F. (2018), "Practitioners' views on intellectual capital and sustainability: From a performance-based to a worth-based perspective", Journal of Intellectual Capital, Vol. 19 No, 2, pp. 367-386.

Oliver, C. (1996), "The institutional embeddedness of economic activity", Advances in Strategic Management, Vol. 13, pp. 163-186.

Osterwalder, A. and Pigneur, Y. (2010), Business Model Generation: A Handbook for Visionaries, Game Changers, and Challengers, Wiley, Hoboken, New Jersey, NJ.

O'Rourke, D. (2014), “The science of sustainable supply chains”, Science, Vol. 344, pp. 1124-1127. 
Paritosh, K., Yadav, M., Mathur, S., Balan, V., Liao, W., Pareek, N. and Vivekanand, V. (2018), “Organic fraction of municipal solid waste: overview of treatment methodologies to enhance anaerobic biodegradability", Frontiers in Energy Research, Vol. 6 No. 75, pp. 1-17.

Pfeffer, J. and Salancik, J.R. (1978), The External Control of Organizations, Harper and Row, New York, NY.

Piscicelli, L., Ludden, G.D.S. and Cooper, T. (2018), "What makes a sustainable business model successful? an empirical comparison of two peer-to-peer goods-sharing platforms", Journal of Cleaner Production, Vol. 172, pp. 4580-4591.

Presch, G., Dal Mas, F., Piccolo, D., Sinik, M. and Cobianchi, L. (2020), "The World Health Innovation Summit (WHIS) platform for sustainable development. From the digital economy to knowledge in the healthcare sector", in Ordonez de Pablos, P. and Edvinsson, L. (Eds), Intellectual Capital in the Digital Economy, Routledge, London.

Qu, S.Q. and Dumay, J. (2011), “The qualitative research interview”, Qualitative Research in Accounting \& Management, Vol. 8 No. 3, pp. 238-264.

Reuber, A.R. and Morgan-Thomas, A. (2019), "Communicating moral legitimacy in controversial industries: the trade in human tissue", Journal of Business Ethics, Vol. 154 No. 1, pp. 49-63.

Rothwell, R. (1992), "Successful industrial innovation: critical factors for the 1990s", $R \& D$ Management, Vol. 22 No. 3, pp. 221-240.

Saebi, T., Lien, L. and Foss, N.J. (2017), "What drives business model adaptation? The impact of opportunities, threats and strategic orientation”, Long Range Planning, Vol. 50 No. 5, pp. 567-581.

Sánchez, P. and Ricart, J.E. (2010), "Business model innovation and sources of value creation in lowincome markets", European Management Review, Vol. 7 No. 3, pp. 138-154.

Schniederjans, D.G. and Hales, D.N. (2016), "Cloud computing and its impact on economic and environmental performance: a transaction cost economics perspective", Decis Support Syst, Vol. 86, pp. 73-82.

Sehnem, S., Campos, L.M.S., Julkovski, D.J. and Cazella, C.F. (2019), “Circular business models: level of maturity", Management Decision, Vol. 57 No. 4, pp. 1043-1066.

Singh, P. and Giacosa, E. (2019), "Cognitive biases of consumers as barriers in transition towards circular economy", Management Decision, Vol. 57 No. 4, pp. 921-936.

Sinha, A., Sengupta, T. and Alvarado, R. (2020), "Interplay between technological innovation and environmental quality: formulating the SDG policies for next 11 economies", Journal of Cleaner Production, Vol. 242, pp. 1-12.

Snihur, Y. and Zott, C. (2013), "Legitimacy without imitation: how to achieve robust business model innovation", Academy of Management Proceedings, Vol. 1, p. 12656.

Spiess-Knafl, W., Mast, C. and Jansen, S.A. (2015), "On the nature of social business model innovation”, Social Business, Vol. 5 No. 2, pp. 113-130.

Suchman, M.C. (1995), "Managing legitimacy: strategic and institutional approaches", Academy of Management Review, Vol. 20 No. 3, pp. 571-610.

Suddaby, R., Bitektine, A. and Haack, P. (2017), "Legitimacy", Academy of Management Annals, Vol. 11 No. 1, pp. 451-478.

Tang, Y. (2017), "A summary of studies on organizational legitimacy”, Open Journal of Business and Management, Vol. 5, pp. 487-500.

Teece, D.J. (2010), "Business models, business strategy and innovation”, Long Range Planning, Vol. 43 Nos 2-3, pp. 172-194.

Thomas, T. and Lamm, E. (2012), "Legitimacy and organizational sustainability", Journal of Business Ethics, Vol. 110 No. 2, pp. 191-203.

Tikkanen, H., Lamberg, J., Parvinen, P. and Kallunki, J. (2005), "Managerial cognition, action and the business model of the firm", Management Decision, Vol. 43 No. 6, pp. 789-809. 
Tolbert, P.S. and Zucker, L.G. (1996), "The institutionalization of institutional theory", Handbook of Organization Studies, SAGE, London, pp. 175-190.

Tost, L.P. (2011), "An integrative model of legitimacy judgments", Academy of Management Review, Vol. 36 No. 4, pp. 686-710.

Trequattrini, R., Shams, R., Lardo, A. and Lombardi, R. (2016), "Risk of an epidemic impact when adopting the internet of things: the role of sector-based resistance", Business Process Management Journal, Vol. 22 No. 2, pp. 403-419.

United Nations General Assembly (2005), "2005 world summit outcome, resolution a/60/1, adopted by the general assembly on 15 September, 2005”, in Scott Cato, M. (Ed.), 2009, Green Economics, Earthscan, London, pp. 36-37. ISBN 978-1-84407-571-3.

UNEP United Nations Environment Programme (2012), Annual Report 2012, available at: https:// www.unenvironment.org/resources/annual-report/unep-2012-annual-report.

Walsh, P.P., Murphy, E. and Horan, D. (2020), "The role of science, technology and innovation in the UN 2030 agenda", Technological Forecasting and Social Change, Vol. 154, pp. 1-7.

Wilson, F. and Post, J.E. (2013), "Business models for people, planet (\& profits): exploring the phenomena of social bu siness, a market-based approach to social value creation", Small Business Economics, Vol. 40 No. 3, pp. 715-737.

Wu, J., Guo, S., Huang, H., Liu, W. and Xiang, Y. (2018a), "Information and communications technologies for sustainable development goals: state-of-the-art, needs and perspectives", IEEE Communications, Surveys and Tutorials, Vol. 99, pp. 1-18.

Wu, X., Zhao, Z. and Zhou, B. (2018b), "Legitimacy in adaptive business model innovation: an investigation of academic ebook platforms in China", Emerging Markets Finance and Trade, Vol. 55 No. 4, pp. 719-742.

W.W.F. (2014), Living Planet Report 2014, available at: http://assets.worldwildlife.org/publications/ 723/files/original/WWF-LPR2014-low_res.pdf?1413912230\&_ga=1.18880888.1396751849.148716 5243 (accessed 6 February 2016).

Yin R.K. (2014), Case Study Research: Design and Methods, SAGE, Thousand Oaks, CA.

Yunus, M., Moingeon, B. and Lehmann-Ortega, L. (2010), "Building social business models: lessons from the grameen experience", Long Range Planning, Vol. 43, pp. 308-325.

Zhang, X., Zhang, M., Zhang, H., Jiang, Z., Liu, C. and Cai, W. (2020), "A review on energy, environment and economic assessment in remanufacturing based on life cycle assessment method", Journal of Cleaner Production, Vol. 255, pp. 1-19.

Zimmerman, M.A. and Zeitz, G.J. (2002), "Beyond survival: achieving new venture growth by building legitimacy", Academy of Management Review, Vol. 27 No. 3, pp. 414-431.

Zott, C., Amit, R. and Massa, L. (2011), "The business model: recent developments and future research", Journal of Management, Vol. 37 No. 4, pp. 1019-1042.

Zucker, L.G. (1988), "Where do institutional patterns come from? Organizations as actors in social systems", in Zucker, L.G. (Ed.), Institutional Patterns and Organizations, Ballinger, Cambridge MA, pp. 23-52.

Zuo, J., Zillante, G., Wilson, L., Davidson, K. and Pullen, S. (2012), "Sustainability policy of construction contractors: a review", Renewable and Sustainable Energy Reviews, Vol. 16 No. 6, pp. 3910-3916.

\footnotetext{
About the authors

Roberto Biloslavo is full professor of Management at the University of Primorska, Faculty of Management. His research work is focused on strategic management, wisdom and sustainable development. He is a former Vice-Rector for Academic Affairs and vice-dean for research. Besides teaching and researching, he consults to different domestic and international companies about strategic planning, sustainable business models, CSR, knowledge management and leadership development. He is on the editorial board of a range of journals and regularly reviews for journals and conferences.
} 
In addition, he is involved in different international research projects and acts as a specialist advisor for Slovene qualification framework and Slovene net for corporate responsibility.

Carlo Bagnoli is full professor of Business Policy and Strategy at the Department of Management, Ca' Foscari University of Venice. He received a $\mathrm{PhD}$ in Business Economics at Ca' Foscari University of Venice. He was visiting research fellow at the University of Florida. He is Scientific Director of the Innovarea Project funded by the Regional Italian Government. His research interests include knowledge management, competitive strategy, business model innovation. Carlo's research work has been published in various outlets, including the Journal of Business Economics and Management, Industrial Management and Data System, Journal of Management and Governance and Journal of Intellectual Capital.

Maurizio Massaro, $\mathrm{PhD}$, is associate professor at Ca' Foscari University of Venice. Before joining academia, he was founder and CEO of multiple consultancy firms. He has also served as a research center vice-president in the field of metal analysis. He has been a visiting professor at Florida Gulf Coast University and Leicester University. He enjoys several contacts and research partnerships with universities in the United States, continental Europe, United Kingdom, Asia and Australia. His research interests include knowledge management, intellectual capital, sustainability in international business and research methods. His research has been applied in multiple research contexts. Maurizio Massaro is the corresponding author and can be contacted at: maurizio.massaro@unive.it

Antonietta Cosentino is assistant professor in Business Administration at the University of Rome "La Sapienza" where she teaches the courses of Business Administration (bachelor's degree) and NoProfit Management (master's degree). She was delegate of the Rector of Sapienza at the nonprofit observatory established at the Chamber of Commerce, Industry, Crafts and Agriculture of Rome as the expert of the university. To time, she is the scientific director of the department for numerous agreement protocols with public and private entities. She is guest lecturer at prestigious European universities. Her field of the research is focused on accounting, nonfinancial disclosure, integrated reporting, social value measure, social enterprises, no-profit organization.

For instructions on how to order reprints of this article, please visit our website:

www.emeraldgrouppublishing.com/licensing/reprints.htm

Or contact us for further details: permissions@emeraldinsight.com 